\title{
DESCRIPTION OF EUBRANCHUS INABAI N. SP., FROM MUKAISHIMA, JAPAN (NUDIBRANCHIA- EOLIDOIDEA)
}

\author{
$\operatorname{AUTHOR(S):~}$ \\ Baba, Kikutaro
}

CITATION:

Baba, Kikutaro. DESCRIPTION OF EUBRANCHUS INABAI N. SP., FROM MUKAISHIMA, JAPAN (NUDIBRANCHIA-EOLIDOIDEA). PUBLICATIONS OF THE SETO MARINE BIOLOGICAL LABORATORY 1964, 12(4): 285-287

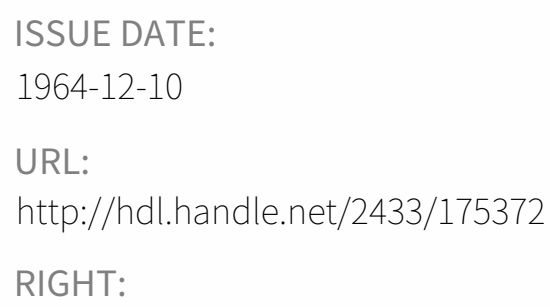




\title{
DESCRIPTION OF EUBRANCHUS INABAI N. SP., FROM MUKAISHIMA, JAPAN (NUDIBRANCHIA-EOLIDOIDEA) ${ }^{1)}$
}

\author{
KIKUTARÓ BABA \\ Biological Laboratory, Osaka Gakugei University, Osaka
}

With 1 Text-figure

The author is grateful to Dr. Akihiko InABA who has kindly allowed him to examine two specimens (one living and the other preserved) of a new species of Eubranchus collected from the vicinity of the Mukaishima Marine Biological Station attached to the Hiroshima University. The descriptive accounts run as follows :

Eubranchus inabai n. sp.

Inaba-minoumiushi (n. n.)

Holotype: Length (Code Ac) $6 \mathrm{~mm}$ in the living state. Body rather stoutish. Tail long and narrowed, but ends bluntly. Rhinophores simple. Branchial papillae on back-margins arranged in 5 simple oblique rows, about 3 in the 1st, 4 in the 2 nd, 2-3 in the $3 \mathrm{rd}$, and 2 in the 4 th and 5 th, the foremost two rows presumably belonging to the right liver (and the left partner), the papillae themselves short fusiform and swollen in the mid-length. Liver diverticulum within each of the papillae simple. Genital orifice immediately below the middle of the right liver rows. Acleioproctic anus closely in front of the inner corner of the post-anal row, nephroproct not determined. Foot-corners rounded. Back and sides deep reddish brown, a series of opaque white markings on the back in the median line, that marking covering the pericardial prominence being the largest. Mid-length of the cephalic tentacles reddish brown. Head above opaque white. Sides of head reddish brown, and this colour extends upward to the bases of the rhinophores. Branchial papillae covered with opaque white dots on the upper half, their veins (=liver diverticula) dark brown above and reddish below.

Holotype locality: Mukaishima, Inland Sea of Seto, Japan.

Date of collection: Mar. 21, 1962 (coll. by Dr. INABA).

1) Contributions from the Mukaishima Marine Biological Station, No. 78.

Publ. Seto Mar. Biol. Lab., XII (4), 1964. (Article 21) 
Paratype: Preserved, length $3 \mathrm{~mm}$. Jaw-edge with a series of about 15 blunt denticles. Radula formula $85 \times 1$.1.1. Central tooth with a median cusp and 2 lateral denticles on each side. Lateral teeth broad and plate-like. Jawplates and radula faintly yellowish. Penis not determined.

Paratype locality: Same as the holotype.

Date of collection: Mar. 4, 1960 (coll. by Dr. INABA).

Remarks: It has been argued by Lemche (1964) to adopt Eolis farrani Alder \& Hancock, 1845 (1844) as the type of Eubranchus Forbes, 1838. The generic

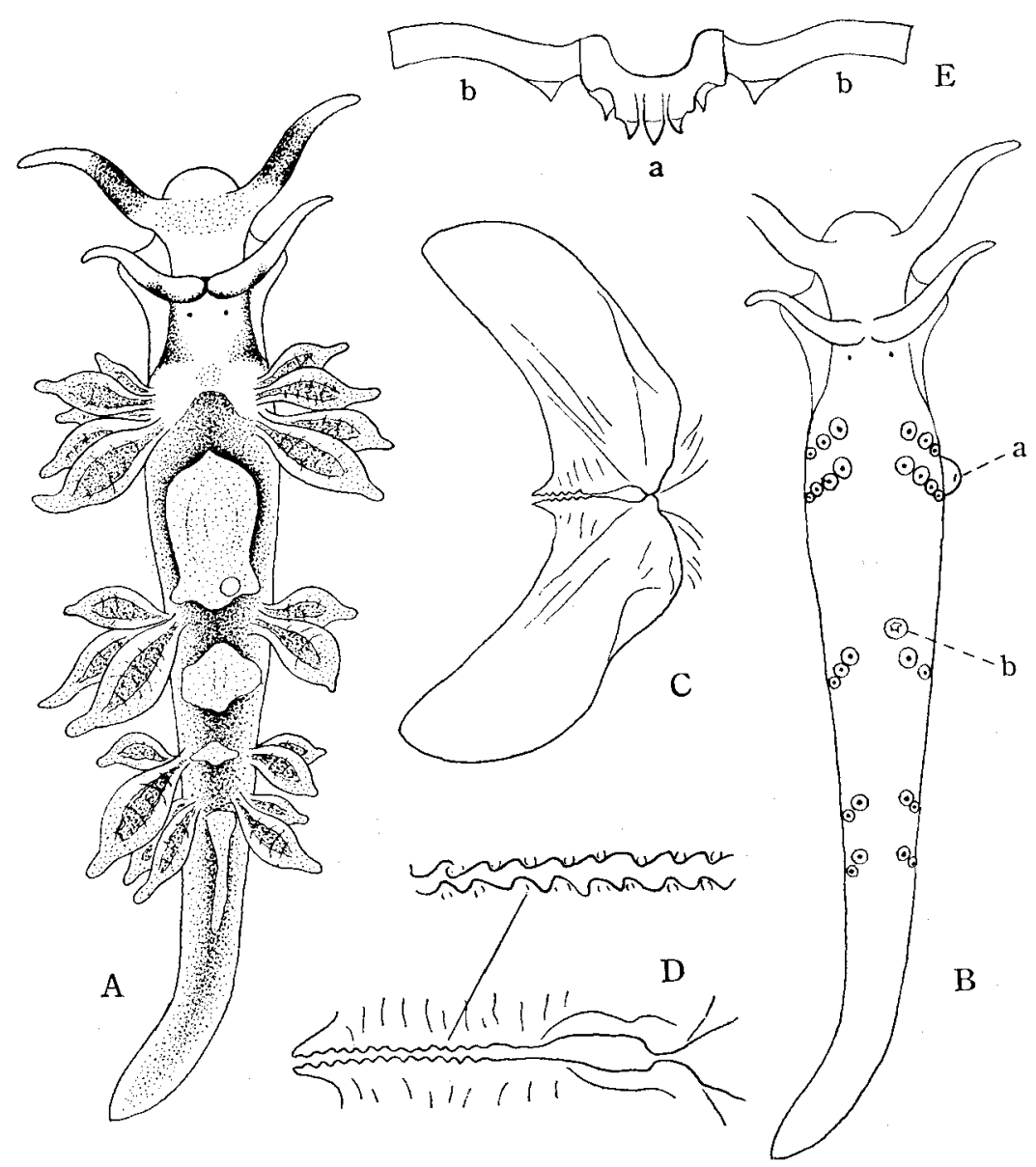

Fig. 1. Eubranchus inabai from Mukaishima, Inland Sea of Seto, Japan.

A-B. Holotype; C-E. Paratype. A. Entire animal in life, length (Code Ac) $6 \mathrm{~mm}$. B. External features of the body, a. genital orifice, b. anal papilla. C. Paired jaw-plates from outside $(\times 30)$. D. Denticulations of the jaw-edge $(\times 100)$. E. A transverse row of radula teeth $(\times 300)$, a. central tooth, b. lateral teeth. 
characters, though not completely, are fairly well-known to-day (see ODHner, 1939, pp. 53, 63; Leмche, 1964, p. 41), and horii BABA, 1960 may possibly be taken in its organization as one of the representative members of Eubranchus (in horii a stylet is present at the tip of the conical, muscular penis). A new species, inabai, is here added to the same genus. Seemingly it resembles most closely E. agrius MARcus, 1959, in the arrangement of the branchial papillae, but differs from the latter in the shape of the central teeth. Contrary to these statements, the species misakiensis $\mathrm{BABA}, 1960$ has been revealed to disagree with Eubranchus in many respects (angulated foot-corners, liver diverticulum with a boss in the mid-length, exceedingly elongated penis gland, formation of a false penis, absence of a stylet, thick development of glandular tissue on the outer wall of the penis sheath). Presumably this species is ought to be transferred to a separate genus not recorded previously. Eubranchopsis virginalis BABA, 1949 forms undoubtedly a distinct species. But it shows the general structure of the genitalia found in usual species of Eubranchus, and has a very small stylet on the muscular penis. It is the author's private intention to give, some day or other in the future, fuller accounts on the comparative anatomy of a series of species, Eubranchus horii, E. (?) misakiensis and Eubranchopsis virginalis.

Note: Two more specimens of $E$. inabai have been obtained from Nomo near Nagasaki in a tide pool covered by hydrozoans (Mar. 28, 1964, collector Mr. K. Matsubayashi).

\section{REFERENCES}

(Continued to the previous papers of the author appeared in the Publications of the Seto Marine Biological Laboratory, vols. IX-XII).

AldDR, J. \& HANCOCK, A. 1845 (1844), 1855. A monograph of the British nudibranchiate Mollusca. Pt. 1 (fam. 3, pl. 35, Eolis farrani); Pt. 7 (pl. 47, suppl., fig. 27, Eolis farrani, radula).

BABA, K. 1960. Two new species of the genus Eubranchus from Japan (Nudibranchia-Eolidacea). Publ. Seto Mar. Biol. Lab., vol. 8, no. 2.

LEMCHE, H. 1964. Eubranchus FoRBES, 1838 (Gastropoda): proposed designation under the plenary powers of a type species, with suppression of several nomina dudia. Z.N. (S.) 1102. Bull. zool. Nomencl., vol. 21, pt. 1.

Marcus, Er. 1959. Lamellariacea und Opisthobranchia. Reports of the Lund University Chile Expedition 1948-49. Lunds Univ. Arrsskr, N. F., Avd. 2, Bd. 55, no. 9. 